\title{
Development and evaluation of tracer particles for use in microzooplankton herbivory studies
}

\author{
Mary Putt \\ Oceanography Department, Old Dominion University, Norfolk, Virginia 23529-0276, USA
}

\begin{abstract}
Two methods of preparing algae for use as tracer particles in single species measurements of microzooplankton herbivory were evaluated. Algae were either heat-killed and labelled with 5- $(4,6-$ dichlorotriazin-2-yl amino fluorescein) (DTAF) (Rublee \& Gallegos 1989; Mar. Ecol. Prog. Ser. 51: 221-227) or stained with hydroethidine (HYD). Both DTAF and HYD-stained algae were readily visible within the digestive vacuoles of most microzooplankton collected in estuarine and coastal waters of Massachusetts (USA) and preserved with Lugol's iodine. However, DTAF was ineffective at staining several chromophytic algae and the heat-kill process reduced cell volume by $\geq 50 \%$ in several of the algae which were effectively stained. HYD effectively stained all algae tested except chlorophytes. Staining with HYD had negligible effects on cell size or morphology but reduced photosynthesis in Isochrysis galbana by about $95 \%$. Ingestion rates of field populations of ciliates differed by up to 25 -fold for 2 algal species (I. galbana and Pyramimonas sp.). For a ciliate (Strombidinopsis sp.) which ingested Pyramimonas sp. at a high rate relative to I. galbana, ingestion rates for live HYD-stained Pyramimonas sp. were about twice as high as for the same alga heat-killed and stained with DTAF. In cultures of Strobilidium sp., ingestion of $\mathrm{HYD}$-stained and untreated I. galbana radiolabelled with ${ }^{14} \mathrm{C}$ were similar at concentrations up to $1.6 \times 10^{4}$ cells ml $\mathrm{m}^{-1}$ HYD dissolved in seawater had negligible effects on ciliate grazing rate at concentrations up to $0.29 \mu \mathrm{g} \mathrm{ml} \mathrm{m}^{-1}$. HYD-stained algae are a new tool for quantifying microzooplankton herbivory which should be particularly useful in examining feeding preferences among field populations.
\end{abstract}

\section{INTRODUCTION}

Microzooplankton ( 2 to $20 \mu \mathrm{m}$ ) herbivory can influence the flow of energy and material through food webs as well as phytoplankton community structure (Frost 1980, Sherr et al. 1986). Both community and single species approaches are currently used to measure microzooplankton herbivory (reviewed in Gifford 1988). Single species approaches are attractive for herbivory measurements from several standpoints. Here, grazing of individual protozoa is measured in short incubations (scale of minutes) with minimal manipulation of the community. This latter feature is important because oligotrichous ciliates, typically a large component of the microzooplankton community, are greatly damaged by seemingly gentle procedures (Gifford 1985). With the single species techniques, grazing estimates are generally based on visual observation of 'surrogate' prey inside the digestive vacuoles of protozoa (McManus \& Fuhrman 1986, McManus \& Okubo 1991). In contrast, most community approaches, e.g. the dilution technique (Landry \& Hassett 1982), require substantial assumptions that microzooplankton grazing is responsible for any change in the measured parameter (Gifford 1988, Gallegos 1989).

An assumption of all single species tracer studies is that protozoan grazing on 'surrogate' and naturally occurring prey are similar (McManus \& Fuhrman 1986, Sherr et al. 1987, McManus \& Okubo 1991). However even in early tracer studies, tintinnids were found to graze yeast, inert carbon particles and cornstarch at different rates (Spittler 1973, Heinbokel 1978). Subsequent studies demonstrated the ability of protozoa to select prey based on particle size (Rassoulzadegan 1978, Capriulo 1982, Jonsson 1986). More recently, food 'quality' was shown to influence particle selection by protozoa (Stoecker et al. 1981, Stoecker et al. 1986, Sanders 1988, Stoecker 1988, Verity 1988).

Prey selectivity could bias the interpretation of single species tracer experiments in the field. Clearly, surrogate prey must resemble natural prey as closely as possible if either quantitative information about grazing rates or qualitative conclusions about predator-prey interactions are to be realistic. Lessard \& Swift (1986) 
addressed this problem by radiolabelling the natural community and determining the appearance of radiolabel in protozoa. Their approach requires a final time-consuming isolation step at the conclusion of the incubation. In field studies, the single cell radioisotope approach is thus limited to reasonably large $(>30$ to $40 \mu \mathrm{m}$ ) morphologically distinct protozoa (Putt 1990a). Microscopic evaluation of particle uptake allows determination of grazing in a larger number of individuals of much greater size range. Identification problems are substantially reduced relative to the single cell isolation approach.

Recently Rublee \& Gallegos (1989) proposed using heat-killed fluorescently labelled algae as surrogate prey in microzooplankton grazing studies (see also Sherr et al. 1991). Heat-killed fluorescently labelled bacteria are now widely used to measure bacterivory in aquatic systems (e.g. Sherr et al, 1987, Pace et al. 1990). In the present study I evaluate the use of algae which were either heat-killed and fluorescently labelled with 5-(4,6-dichlorotriazin-2-yl) amino fluorescein (DTAF) (Rublee \& Gallegos 1989), or stained live with rhodamine 6G, fluorescein diacetate or hydroethidine (Graham 1990, Herman \& Stasz 1990), as tracers in microzooplankton herbivory studies.

\section{METHODS}

Culture and collection of algae and ciliates. Algae (Table 1) were grown in a 12:12 light:dark cycle at about $100 \mu \mathrm{E} \mathrm{m}^{-2} \mathrm{~s}^{-1}$ on $\mathrm{f} / 2$ medium with silica added to all diatom cultures. All strains were grown at $20^{\circ} \mathrm{C}$ except for Nitzschia sp., Detonula confervacea and an unidentified prasinophyte (CCMP 39) which were grown at $4{ }^{\circ} \mathrm{C}$. Cultures had reached early-mid stationary phase ( 7 to $14 \mathrm{~d}$ following inoculation) at the time of staining.

Natural populations of ciliates collected from surface waters of Vineyard Sound and Eel Pond (Massachusetts, USA) during July 1990 were generally used (Table 2). For one experiment (see below), several isolates of Strobilidium sp. grown in culture with Isochrysis galbana, Heterocapsa pygmaea and Pyrenomonas salina as food sources were used (Putt 1990b).

Staining. Heat-killed fluorescently labelled algae were prepared with DTAF according to the procedure of Rublee \& Gallegos (1989). Cells were concentrated by centrifugation, resuspended in phosphate buffer and incubated with DTAF $\left(0.2 \mathrm{mg} \mathrm{ml}^{-1}\right)$ at $55^{\circ} \mathrm{C}$ for $1 \mathrm{~h}$. DTAF-stained algae were stored at $4{ }^{\circ} \mathrm{C}$ in $0.02 \mathrm{M}$ tetrasodium phosphate-buffered saline $(0.85 \%)$ (Sherr et al. 1987). Samples were vortexed and passed through a 20 or $8 \mu \mathrm{m}$ mesh to remove clumps or cell debris prior to use in feeding experiments.
Table 1. Algae tested for staining with DTAF using the method of Rublee \& Gallegos (1989) or hydroethidine (HYD). CCMP culture designation in parentheses. Results were judged excellent $(++)$ if staining was highly visible and uniform within and among individuals, good $(+)$ if staining was visible but not completely uniform within or among individuals, poor $(-)$ if cells did not stain or, for the DTAF-treated cells, if they disintegrated during the procedure. ND: no data

\begin{tabular}{|c|c|c|c|}
\hline \multirow{2}{*}{\multicolumn{2}{|c|}{ Alga }} & \multicolumn{2}{|c|}{ Stain } \\
\hline & & DTAF & HYD \\
\hline \multicolumn{4}{|l|}{ Dinoflagellates } \\
\hline Heterocapsa pygmaea & (GYMNO) & ND & ++ \\
\hline Heterocapsa triguetra & (HT984) & ND & ++ \\
\hline Prorocentrum micans & (PRORO) & ND & + \\
\hline \multicolumn{4}{|l|}{ Prymnesiophytes } \\
\hline Isochrysis galbana & (ISO) & -2 & ++ \\
\hline Isochrysis tahitiana & $(\mathrm{T}-\mathrm{ISO})$ & ND & +- \\
\hline Phaeocystis sp. & $(677-3)$ & ND & $+\perp$ \\
\hline \multicolumn{4}{|l|}{ Diatoms } \\
\hline Thalassiosira weissflogii & (ACTIN) & ND & ++ \\
\hline Nitzschia sp. & & ++ & ++ \\
\hline Detonula confervacea & (DCONF) & ND & + \\
\hline \multicolumn{4}{|l|}{ Cryptophytes } \\
\hline Pyrenomonas salina & & - & ++ \\
\hline \multicolumn{4}{|l|}{ Prasinophytes } \\
\hline Pyramimonas sp. & $(1310)$ & ++ & + \\
\hline Unidentified & (39) & ND & + \\
\hline \multicolumn{4}{|l|}{ Chlorophytes } \\
\hline Dunaliella tertiolecta & (DUN) & + & - \\
\hline Nannochloris sp. & & ++ & - \\
\hline Tetraselmis sp. & & ND & - \\
\hline \multicolumn{4}{|c|}{$\begin{array}{l}\text { " Alga was successfully stained if } \mathrm{NaCl} \text { was added prior to } \\
\text { heating (see text) }\end{array}$} \\
\hline
\end{tabular}

A stock solution (15 $\mathrm{mg} \mathrm{m}^{-1}$ ) of rhodamine-6G (R6G) was prepared in absolute ethanol. Stock solutions of fluorescein diacetate (FDA, $5 \mathrm{mg} \mathrm{ml}^{-1}$ ) and hydroethidine (HYD, $14 \mathrm{mg} \mathrm{ml}^{-1}$ ) were prepared in dimethyl sulfoxide. All stains were purchased from Sigma except for HYD (Dye Lot 94344) which was purchased from Polysciences. Except as noted, live algae were stained using final concentrations of FDA, R6G and HYD of 25,8 and $14 \mu \mathrm{g} \mathrm{ml}^{-1}$ respectively for 5 or $60 \mathrm{~min}$.

During the initial screening, algae were examined both live and following fixation with glutaraldehyde, hexamethylene-buffered formaldehyde $2 \%$ final concentration; Stoecker et al. 1987) or $5 \%$ acid Lugol's iodine. Lugol's fixed samples were cleared with a drop of saturated sodium thiosulfate solution prior to examination. Samples were examined with a Zeiss OM-2 microscope using either transmitted light microscopy or epifluorescence. All stained algae were examined with blue light excitation (Zeiss filter set 4877 09). 
Table 2. Dimensions of ciliates used in feeding experiments

\begin{tabular}{|c|c|c|c|}
\hline Ciliate & $\begin{array}{c}\text { Diameter } \\
\quad(\mu \mathrm{m})\end{array}$ & $\begin{array}{l}\text { Length } \\
(\mu \mathrm{m})\end{array}$ & Experiment \\
\hline $\begin{array}{l}\text { Oligotrichs } \\
\text { Strombidium sp. A. }\end{array}$ & $15-20$ & $27-30$ & $\begin{array}{l}\text { Time course } \\
\text { Toxicity of dissolved HYD }\end{array}$ \\
\hline Strombidium sp. B & $15-25$ & $25-45$ & $\begin{array}{l}\text { Food preference } \\
\text { Toxicity of dissolved HYD }\end{array}$ \\
\hline Strombidinopsis sp. & $30-45$ & $75-105$ & Food preference \\
\hline Strobilidium sp. A & $30-40$ & $40-50$ & Toxicity of dissolved HYD \\
\hline Strobilidium sp. ${ }^{a}$ & $33-46$ & $38-56$ & Ingestion of radiolabelled algae \\
\hline $\begin{array}{l}\text { Tintinnids } \\
\text { Tintinnopsis acuminata }\end{array}$ & $15-24$ & $25-35$ & $\begin{array}{l}\text { Food preference } \\
\text { Toxicity of dissolved HYD }\end{array}$ \\
\hline Tintinnopsis sp. & $15-20$ & $35-50$ & $\begin{array}{l}\text { Food preference } \\
\text { Toxicity of dissolved HYD }\end{array}$ \\
\hline Stensomella sp. & $30-40$ & $60-75$ & Toxicity of dissolved HYD \\
\hline
\end{tabular}

HYD-stained samples were also examined with UV excitation (Zeiss filter set 4877 02).

Photosynthesis measurements. An aliquot of a culture of Isochrysis galbana (ISO) was initially stained with HYD for a period of $60 \mathrm{~min}$. Photosynthesis was measured in untreated and formaldehyde-killed $I$. galbana, as well as HYD-stained I. galbana (HYD-ISO) by ${ }^{14} \mathrm{C}$ uptake (Putt 1990b). Irradiance and temperature were the same during the ${ }^{14} \mathrm{C}$ uptake experiment as during growth of the algal culture.

Incubation protocols. DTAF or HYD-stained Isochrysis galbana (referred to subsequently as DTAF-ISO or HYD-ISO) or Pyramimonas sp. (DTAF-PYR or HYDPYR) were added to samples contained in polycarbonate jars. Except as noted, incubations were $30 \mathrm{~min}$ in length. Incubations were carried out on the lab bench at a temperature $\pm 2^{\circ} \mathrm{C}$ of the sea surface or growth chamber temperature. Jars were gently swirled at roughly $5 \mathrm{~min}$ intervals to maintain food particles in suspension. Samples (100 to $250 \mathrm{ml})$ collected at the beginning and end of the incubation were fixed in Lugol's iodine, settled in $100 \mathrm{ml}$ chambers and cleared with sodium thiosulfate.

The most abundant ciliate taxa in each sample (Table 2) were scored for ingestion of particles. For most taxa, 30 to 100 cells were scored per replicate sample. An exception was the large ciliate Strombidinopsis sp., for which 5 to 20 cells were scored per replicate sample. Dimensions of ciliates and stained algae were measured with a calibrated ocular mi- crometer at magnifications of 400 and $1000 \times$ respectively. Final concentrations of added algae (typically 0.5 to $1 \times 10^{4} \mathrm{cell} \mathrm{ml}^{-1}$ ) were determined in aliquots of the incubated sample using a haemocytometer.

Experimental protocols. Time course: HYD-ISO was added to a $1 \mathrm{l}$ sample at a concentration of $3.3 \times 10^{4}$ cells $\mathrm{ml}^{-1}$, (final concentration of dissolved HYD, $\left.0.14 \mu \mathrm{g} \mathrm{ml}^{-1}\right)$. One subsample $(250 \mathrm{ml})$ was fixed at 10 min intervals over a period of $30 \mathrm{~min}$. This was the only experiment in which a time course was conducted.

Particle concentration: HYD-ISO was added at concentrations ranging from 0.2 to $7 \times 10^{4}$ cells $\mathrm{ml}^{-1}$ (final concentration of dissolved HYD, 0.001 to $0.286 \mu \mathrm{g} \mathrm{ml}^{-1}$ ) to individual $250 \mathrm{ml}$ samples.

Food preference: HYD-ISO, HYD-PYR and DTAFPYR were added to separate sets of triplicate $250 \mathrm{ml}$ samples at concentrations of 0.9 to $1 \times 10^{4}$ cells ml $\mathrm{ml}^{-1}$ (final concentration of dissolved HYD, 0.10 to $0.20 \mu \mathrm{g}$ $\left.\mathrm{ml}^{-1}\right)$.

Toxicity of dissolved HYD: In the first experiment, HYD (final conc. $0.29 \mu \mathrm{g} \mathrm{ml}^{-1}$ ) was added to one of 2 sets of triplicate $250 \mathrm{ml}$ samples immediately prior to the incubation. Ingestion of DTAF-PYR $\left(0.6 \times 10^{4}\right.$ cells $\mathrm{ml}^{-1}$ ) was evaluated in the presence and absence of HYD.

In the second experiment, HYD-ISO was prepared using the standard protocol. An aliquot was centrifuged and washed once with sterile seawater to remove most of the dissolved HYD. Ciliate ingestion of the washed and unwashed HYD-ISO $\left(0.7 \times 10^{4}\right.$ cells 
$\left.\mathrm{ml}^{-1}\right)$ was compared in triplicate samples. The concentration of HYD in the sample containing unwashed HYD-ISO was $0.05 \mu \mathrm{g} \mathrm{ml} \mathrm{m}^{-1}$.

Ingestion of radiolabelled Isochrysis galbana by Strobilidium sp. in culture: This is the only set of experiments which used ciliate cultures. Radiolabelled I. galbana $\left({ }^{14} \mathrm{C}\right.$-ISO) was prepared by growing the alga in the presence of $\mathrm{NaH}^{14} \mathrm{CO}_{3}\left(1 \mu \mathrm{Ci} \mathrm{m}{ }^{-1}\right)$ for at least 3 d. Radiolabelled algae were then stained with $\mathrm{HYD}$ (HYD- ${ }^{14} \mathrm{C}$-ISO).

In the first experiment, grazing on stained and unstained radiolabelled algae was determined from microscopy and using single species radioisotopic methods respectively. To determine grazing on stained algae, HYD- ${ }^{14} \mathrm{C}$-ISO was added to an aliquot of the Strobilidium sp. culture and ingestion determined microscopically using standard protocols. To measure grazing on unstained cells, ${ }^{14} \mathrm{C}$-ISO was added to a second aliquot of the Strobilidium $\mathrm{sp}$. culture at an identical concentration as the HYD $-{ }^{14} \mathrm{C}$-ISO used in the microscopy study. Ciliates isolated from this culture at the initiation of the experiment and after $30 \mathrm{~min}$ were passed through 2 serial washes and placed into triplicate scintillation vials ( 15 to 40 cells vial ${ }^{-1}$ ).

Samples of the radiolabelled algal culture and the ciliate culture containing radiolabelled algae were also collected for the determination of radiolabel (algal cell $)^{-1} \quad\left(\right.$ DPM $\left._{\text {alga }}\right)$ and total added radioactivity $\left(D_{P} M_{\text {total }}\right)$. Since only the radioactivity within algal or ciliate cells was of interest, inorganic ${ }^{14} \mathrm{C}$ was removed from all vials by addition of $1 \mathrm{ml}$ of a $5 \%$ acetic acid : methanol solution to each vial and evaporation to dryness at $60^{\circ} \mathrm{C}$. Samples were rehydrated with $0.5 \mathrm{ml}$ of water and radioactivity determined.

In 2 subsequent experiments, ingestion of both HYDstained and unstained radiolabelled algae was determined from radioisotopic measurements. Prior to the experiment, inorganic ${ }^{14} \mathrm{C}$ and dissolved HYD were largely removed by centrifuging algae and resuspending them in $2 \mathrm{ml}$ of fresh media prior to addition to the ciliate culture. Radioisotope content of ciliates was determined at the initiation of the experiment and after $30 \mathrm{~min}$.

Calculations. Ingestion rates are based on endpoint determinations of particle ingestion. For all except time course and particle concentration experiments, reported ingestion rates were corrected for 'ingestion of particles' in time zero controls. In microscopy experiments, time zero controls were consistently less than $10 \%$ of endpoint values.

In the radiolabelling experiments, hourly clearance rate (CR) was determined from

$$
C R=\left(D_{\text {cilata }} / \mathrm{DPM}_{\text {tota. }}\right)(1 / t)
$$

where $D P M_{\text {citate }}=$ radioactivity per ciliate at the end of the incubation corrected for the radioactivity per ciliate at time zero; DPM $_{\text {total }}=$ radioactivity in particulate material added to the ciliate culture; and $t=$ time (h).

Ingestion rate (IR) was determined from

$$
\mathrm{IR}=\left(\mathrm{DPM}_{\text {cliate }} / \mathrm{DPM}_{\text {alga }}\right)(1 / t)
$$

where DPM alga $=$ radioactivity per algal cell.

\section{RESULTS}

\section{Initial screening of stains}

Several chlorophytes, a prasinophyte and a diatom were successfully heat-killed and stained with DTAF following the procedure of Rublee \& Gallegos (1989) (Table 1). The prymnesiophyte Isochrysis galbana and the cryptophyte Pyrenomonas salina disintegrated during the heat-kill step of the DTAF procedure (Table 1). For I. galbana, the addition of $\mathrm{NaCl}\left(100 \mathrm{mg} \mathrm{ml}^{-1}\right.$ final conc.) to the phosphate buffer immediately before addition of DTAF greatly reduced disintegration of the cells during the heat-kill process and allowed preparation of a DTAF-stained sample. Longest dimensions and cell volumes were the same in DTAF-PYR and untreated Pyramimonas sp. (Table 3). Longest dimensions of DTAF-ISO and DTAF-stained Dunaliella ter-

Table 3. Size of untreated algae and algae stained with HYD or DTAF. HYD-stained cells were not treated with fixative prior to

\begin{tabular}{|c|c|c|c|c|c|c|}
\hline \multirow[t]{3}{*}{ Alga } & \multicolumn{2}{|c|}{ Untreated cultures } & \multicolumn{4}{|c|}{ Ratio } \\
\hline & \multirow{2}{*}{$\begin{array}{l}\text { Longest } \\
\text { dimension } \\
\qquad(\mu \mathrm{m})\end{array}$} & \multirow{2}{*}{$\begin{array}{l}\text { Volume } \\
\left(\mu \mathrm{m}^{3}\right)\end{array}$} & \multicolumn{2}{|c|}{ HYD: untreated } & \multicolumn{2}{|c|}{ DTAF: untreated } \\
\hline & & & $\begin{array}{l}\text { Longest } \\
\text { dimension }\end{array}$ & Volume & $\begin{array}{l}\text { Longest } \\
\text { dimension }\end{array}$ & Volume \\
\hline Nitzschia sp. & $3.9 \pm 0.1$ & $13 \pm 1$ & ND & ND & 1.1 & 1.0 \\
\hline Isochrysis galbana (ISO) & $4.5 \pm 0.2$ & $38 \pm: 3$ & 1.0 & 0.9 & 0.7 & 0.4 \\
\hline Dunaliella tertiolecta (DUN) & $5.3 \pm 0.2$ & $112 \pm 8$ & 1.0 & 1.0 & 0.8 & 0.5 \\
\hline Pyramimonas sp. $(1310)$ & $8.3 \pm 0.2$ & $128 \pm 15$ & 1.0 & 1.0 & 1.1 & 1.1 \\
\hline
\end{tabular}
measurement. Means \pm SEM $(\mathrm{n}=10$ to 30 ). ND: no data 


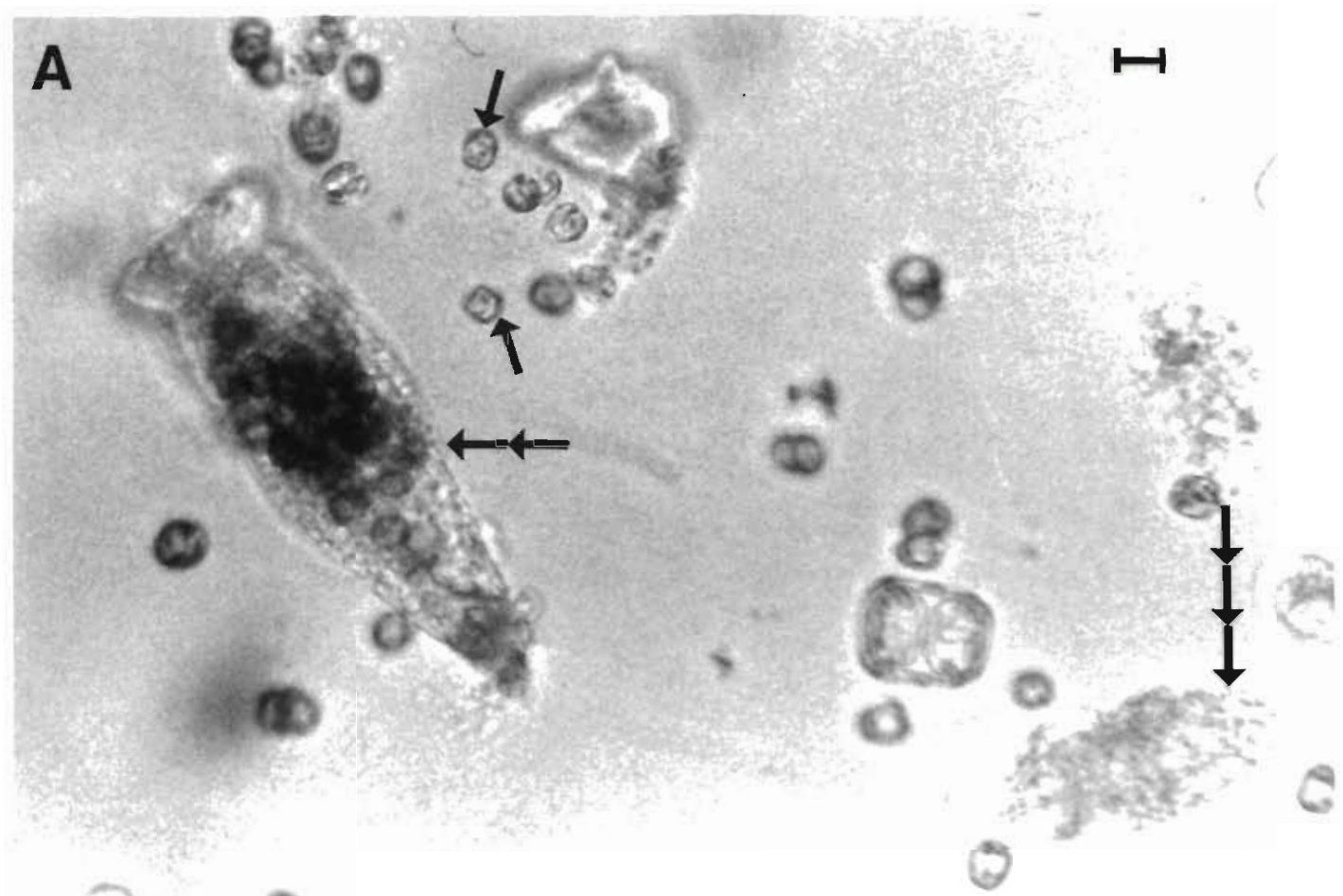

B

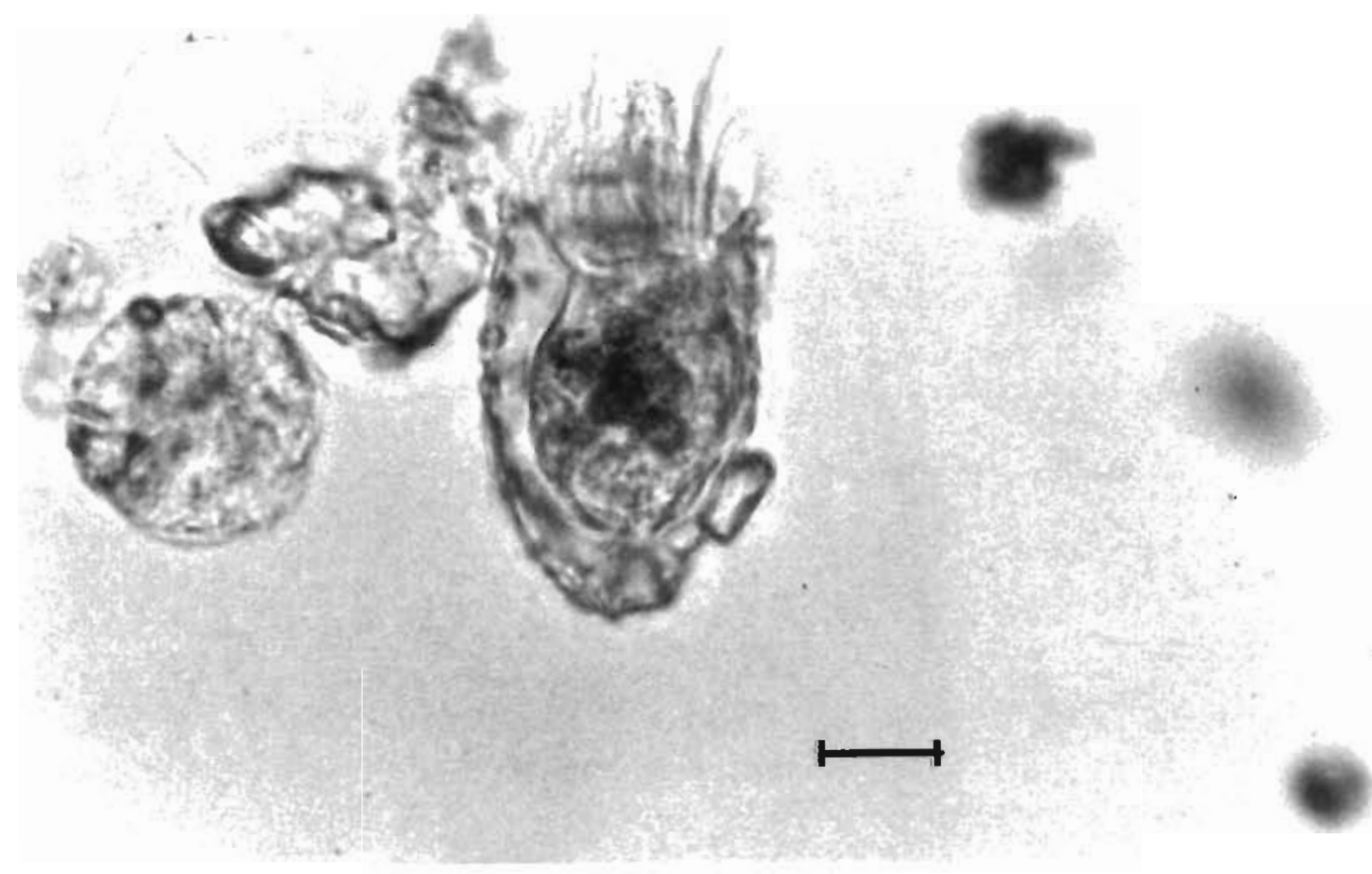

Fig. 1 (A) HYD-stained Pyramimonas sp. ingested by Strombidinopsis sp. (B) HYD-stained Isochrysis galbana ingested by Tintinnopsis acuminata. Double arrow. Strombidinopsis sp. with ingested particles; triple arrow: Strombidium sp. without ingested particles; single arrows: group of HYD-stained Pyramimonas sp. All samples were collected from Vineyard Sound, Massachusetts, USA. Scale bars $=10 \mu \mathrm{m}$ 
tiolecta (DTAF-DUN) were 70 to $80 \%$ of unstained cells while volumes were 40 to $50 \%$ of unstained cells.

Live Heterocapsa triquetra or Isochrysis galbana stained with FDA or R6G for 5 or $60 \mathrm{~min}$ fluoresced brightly. Within $1 \mathrm{~h}$ of fixation with glutaraldehyde or formaldehyde, cellular fluorescence decreased or background fluorescence increased to the point where stained and unstained cells were indistinguishable. Fluorescence in live HYD-ISO was brilliant in preparations examined immediately after staining periods of 0.3 to $1 \mathrm{~h}$. After fixation with glutaraldehyde or formaldehyde, fluorescence in HYD-ISO faded less than did cells stained with FDA or R6G but individual cells could not be distinguished within the digestive vacuoles of ciliates.

However HYD-ISO viewed with transmitted light microscopy retained a distinct pink color in samples fixed with Lugol's iodine and cleared with sodium thiosulfate. FDA and R6G stained ISO were colorless after fixation with Lugol's iodine and clearing with sodium thiosulfate. Color development was better when the HYD staining procedure was carried out in the presence of light on a lab bench or in the illuminated incubator where the algae were grown, than when staining was carried out in the dark. HYDstained ISO were easily distinguished from unstained ISO. In total, 12 strains from 5 algal groups retained a distinct pink through brown color following this staining/fixation procedure (Table 1). Only the chlorophytes consistently remained unstained following treatment with HYD. Cell size in 4 algae was unaffected by treatment with HYD (Table 3 ). In samples preserved with Lugol's iodine and cleared with sodium thiosulfate, HYD-PYR and HYD-ISO were clearly visible in the digestive vacuoles of a number of ciliate taxa and some heterotrophic dinoflagellates (Fig. 1).

Compared to an unstained sample, motility of ISO was greatly reduced within $15 \mathrm{~min}$ of addition of HYD $\left(14 \mu \mathrm{g} \mathrm{m} \mathrm{m}^{-1}\right.$ ). Photosynthetic activity in HYD-ISO (prestained with $14 \mathrm{ug} \mathrm{ml}^{-1}$ HYD for $1 \mathrm{~h}$ ) was detectable but was only 3 to $5 \%$ of live ISO (Table 4 ). Reduction of stain concentration to even $7 \mu \mathrm{g} \mathrm{ml}^{-1}$ or use of a staining period shorter than ca 1 h unacceptably reduced stain quality.

Table 4. Isochrysis galbana. Assimilation of radiolabelled carbon (disintegrations $\mathrm{min}^{-1}$ ) in the light in 2 experiments in the presence or absence of HYD. Means $\pm \operatorname{SEM}(\mathrm{n}=3)$

\begin{tabular}{|lcc|}
\hline Killed control & \multicolumn{2}{c|}{ Live algae } \\
& HYD absent $\quad$ HYD present \\
& \multicolumn{2}{|c|}{ (DPM) } \\
\hline $82 \pm 2$ & $2079 \pm 66$ & $152 \pm 7$ \\
$88 \pm 24$ & $1207 \pm 25$ & $147 \pm 5$ \\
\hline
\end{tabular}

After $1 \mathrm{~h}$, about $15 \%$ of the cells failed to stain pink as viewed with transmitted light even though these cells assimilated HYD as indicated by cellular fluorescence. Staining periods up to $4 \mathrm{~h}$ in length did not substantially reduce the proportion of unstained cells. Hence cells were stained for $1 \mathrm{~h}$ in HYD at a concentration of $14 \mu \mathrm{g} \mathrm{ml}^{-1}$ for the experiments reported here. Only stained cells were included in the final algal count.

\section{Incubations}

Time course. Ingestion of HYD-ISO by $<50 \mu \mathrm{m}$ tintinnids and Strombidium sp. A was linear up to $30 \mathrm{~min}$ (Fig. 2).

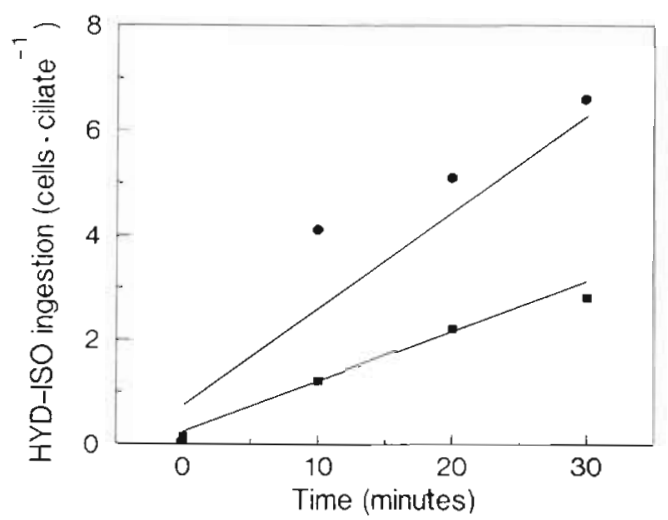

Fig. 2. Ingestion of HYD-ISO by Strombidium sp. A ( $\bullet$ ) and tintinnids $<40 \mu \mathrm{m}$ in length ( $\bullet$ ) over time in field populations collected from Vineyard Sound. Concentration of added HYD. ISO was $3.3 \times 10^{4}$ cells $\mathrm{ml}^{-1}$. One sample was processed at each time point

Particle concentration. For Strombidium sp. A, uptake of HYD-ISO increased up to a HYD-ISO concentration of about $1.5 \times 10^{4}$ cells ml ${ }^{-1}$ (Fig. $3 \mathrm{~A}$ ). Combined results of 2 experiments indicated that uptake of HYD-ISO by Tintinnopsis acuminata also increased up to about $3 \times 10^{4}$ cells $\mathrm{ml}^{-1}$. Particle uptake was constant or decreased slightly between about 3 and $7 \times 10^{4}$ cells $\mathrm{ml}^{-1}$ (Fig. 3B).

Food preference. All 3 ciliates ingested HYD-ISO and HYD-PYR at different rates (Table 5). Strombidinopsis sp., the largest ciliate in this study (Table 2), ingested HYD-PYR, the larger particle used in the study (Table 3), about twice as fast as HYD-ISO. Strombidinopsis sp. ingested HYD-PYR about twice as fast as DTAF-PYR even though the 2 particles were of identical size (Tables $3 \& 5$ ).

The smaller ciliates (Strombidium sp. B and Tintinnopsis sp.) ingested HYD-ISO 8 to 25 times as fast as 
Table 5. Ingestion of hydroethidine-stained Isochrysis galbana (HYD-ISO), Pyramimonas sp. (HYD-PYR) and heat-killed fluorescently labelled Pyramimonas sp. (DTAF-PYR) by natural ciliate populations collected from Vineyard Sound. Means \pm SEM $(\mathrm{n}=3)$

\begin{tabular}{|lrcrrr|}
\hline Ciliate & HYD-ISO & $\begin{array}{c}\text { Ingestion rate } \\
\text { HYD-PYR } \\
\text { (cells ciliate }{ }^{-1} \mathrm{~h}^{-1} \text { ) }\end{array}$ & DTAF-PYR & $\begin{array}{c}\text { HYD-ISO: } \\
\text { HYD-PYR }\end{array}$ & $\begin{array}{c}\text { RYD-PYR: } \\
\text { DTAF-PYR }\end{array}$ \\
\hline Strombidium sp. B & $8.2 \pm 0.9$ & $1.0 \pm 0.2$ & $1.0 \pm 0.4$ & 8.2 & 1.0 \\
Tintinnopsis sp. & $10.0 \pm 1.3$ & $0.4 \pm 0.1$ & $0.6 \pm 0.1$ & 25.0 & 0.7 \\
Strombidinopsis sp. & $11.2 \pm 0.5$ & $26.2 \pm 1.5$ & $12.6 \pm 1.1$ & 0.4 & 2.1 \\
\hline
\end{tabular}

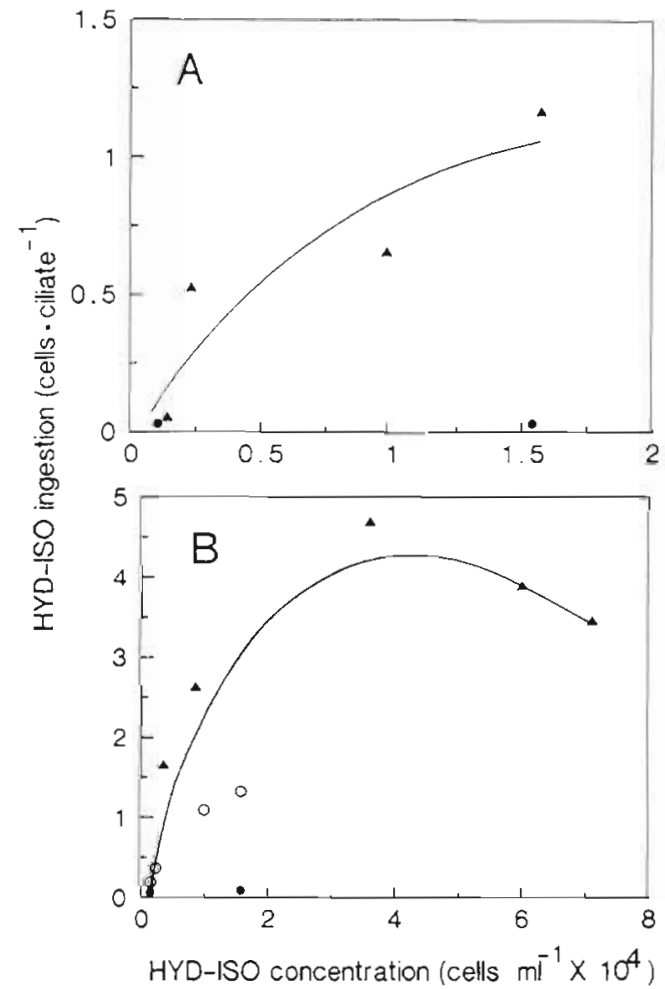

Fig. 3. Ingestion of different concentrations of HYD-ISO by (A) Strombidium sp. and (B) Tintinnopsis acuminata in field populations collected from Vineyard Sound $(0, \mathbf{1}$ : separate experiments). (•) Time zero values. One sample was processed at each particle concentration. Note different scales. Curves drawn by eye

HYD-PYR (Tables $2 \& 5$ ). These ciliates ingested HYDPYR and DTAF-PYR at similar rates.

Toxicity of dissolved hydroethidine. In these experiments, the ratio of ingestion of DTAF-PYR or ISO in the presence and absence of dissolved HYD ranged from 0.7 to 1.4 (Tables $6 \&$ 7). ANOVA indicated no significant effect of HYD on the ingestion of particles. In the second experiment, however, the ANOVA indicated interaction between presence of HYD and species suggesting that HYD may differentially affect ingestion of particles among species (Table 7).
Table 6. Ingestion of DTAF-PYR $\left(0.6 \times 10^{4}\right.$ cells ml $\left.^{-1}\right)$ with or without added hydroethidine (HYD) by natural ciliate populations from Vineyard Sound. Means $\pm \operatorname{SEM}(\mathrm{n}=3)$. Final concentration of added HYD was $0.29 \mathrm{\mu g} \mathrm{ml}^{-1}$

\begin{tabular}{|c|c|c|c|c|}
\hline \multirow[t]{2}{*}{ Ciliate } & \multicolumn{4}{|c|}{ DTAF-PYR uptake } \\
\hline & \multicolumn{3}{|c|}{$\begin{array}{l}- \text { HYD } \quad+\text { HYD } \\
\text { (cells ciliate }{ }^{-1} h^{-1} \text { ) }\end{array}$} & $\begin{array}{l}\text { +HYD: } \\
\text {-HYD }\end{array}$ \\
\hline Stensomella sp. & \multicolumn{2}{|c|}{$1.0 \pm 0.1$} & $1.4 \pm 0.2$ & 1.4 \\
\hline Tintinnopsis sp. & \multicolumn{2}{|c|}{$3.6 \pm 0.8$} & $2.6 \pm 0.2$ & 0.7 \\
\hline Strombidium sp. A & \multicolumn{2}{|c|}{$1.6 \pm 0.2$} & $1.4 \pm 0.2$ & 0.9 \\
\hline Strobilidium sp. A & \multicolumn{2}{|c|}{$4.2 \pm 1.0$} & $3.2 \pm 1.4$ & 0.8 \\
\hline \multicolumn{5}{|c|}{ Two-way ANOVA (NS: not significant at $p<0.05$ ) } \\
\hline Source of variation & di & MS & Fs & \\
\hline Presence of HYD & 1 & 1.4 & 4.5 & NS \\
\hline Ciliate species & 3 & 7.0 & 6.3 & $p<0.005$ \\
\hline Interaction & 3 & 0.9 & 3.2 & NS \\
\hline Error & 16 & 0.4 & & \\
\hline
\end{tabular}

Table 7. Ingestion of washed and unwashed HYD-ISO $0.7 \times$ $10^{4}$ cells $\mathrm{ml}^{-1}$ ) by natural ciliate populations collected from Vineyard Sound. Means I SEM $(\mathrm{n}=3)$. Final concentration of dissolved HYD was $0.05 \mu \mathrm{g} \mathrm{mi}^{-1}$

\begin{tabular}{|c|c|c|c|}
\hline \multirow[t]{2}{*}{ Ciliate } & \multicolumn{3}{|c|}{ HYD-ISO uptake } \\
\hline & \multicolumn{2}{|c|}{$\begin{array}{l}- \text { HYD } \quad \text { HYD } \\
\text { (cells ciliate }{ }^{-1} h^{-1} \text { ) }\end{array}$} & \multirow{2}{*}{$\begin{array}{c}\begin{array}{c}\text { +HYD: } \\
\text { - HYD }\end{array} \\
0.8\end{array}$} \\
\hline Stensomella sp. A & $7.6 \pm 0.5$ & $6.2 \pm 0.6$ & \\
\hline Tintinnopsis spp. & $3.6 \pm 0.8$ & $2.6 \pm 0.2$ & 0.7 \\
\hline Strombidium sp. B & $3.8 \pm 0.5$ & $5.0 \pm 0.3$ & 1.3 \\
\hline \multicolumn{4}{|c|}{$\begin{array}{l}\text { a Combination of Tintinnopsis acuminata and Tintinnopsis } \\
\text { sp. (Table 1) }\end{array}$} \\
\hline \multicolumn{4}{|c|}{ Two-way ANOVA (NS: not significant at $p<0.05$ ) } \\
\hline Source of variation & df $\quad M$ & S $\quad$ Fs & \\
\hline Presence of HYD & 1 & 5.0 & NS \\
\hline Ciliate species & 12 & 9.4 & $p<0.005$ \\
\hline Interaction & 2 & 5.5 & $p<0.025$ \\
\hline Error & 10 & & \\
\hline
\end{tabular}


Table 8. Ingestion of untreated and hydroethidine-stained Isochrysis galbana radiolabelled with ${ }^{14} \mathrm{C}\left({ }^{14} \mathrm{C}\right.$-ISO) by Strobilidium sp. grown in culture. Means $\pm \operatorname{SEM}(n=3)$ except as noted

\begin{tabular}{|c|c|c|c|c|c|}
\hline \multicolumn{2}{|c|}{ Concentration of ISO } & \multicolumn{2}{|c|}{ Particle uptake } & \multicolumn{2}{|c|}{ Clearance rate } \\
\hline Added & Total & Without HYD & With HYD & Without HYD & With HYD \\
\hline \multicolumn{2}{|c|}{$\left(\right.$ cells $\left.\mathrm{ml}^{-1} \times 10^{4}\right)$} & \multicolumn{2}{|c|}{ (cells ciliate $\mathrm{h}^{-1}$ ) } & \multicolumn{2}{|c|}{$\left(\mu \mathrm{l}\right.$ ciliate $\left.\mathrm{e}^{-1} \mathrm{~h}^{-1}\right)$} \\
\hline 0.4 & 4.3 & $46 \pm 6$ & $41 \pm 11^{a}$ & $7.6 \pm 0.8$ & $9.2 \pm 2.4^{\mathrm{a}}$ \\
\hline 1.3 & 1.6 & $49 \pm 7$ & $45 \pm 1$ & $3.6 \pm 0.6$ & $3.7 \pm 0.1$ \\
\hline 4.2 & 4.7 & $340 \pm 18$ & $71 \pm 13$ & $8.0 \pm 0.4$ & $1.6 \pm 0.3$ \\
\hline
\end{tabular}

Ingestion of radiolabelled Isochrysis galbana. When ${ }^{14} \mathrm{C}$-ISO was added at a concentration of 0.4 or $1.3 \times$ $10^{4}$ cells $\mathrm{ml}^{-1}$ Strobilidium sp. ingested $\mathrm{HYD}-{ }^{14} \mathrm{C}$-ISO and untreated ${ }^{14} \mathrm{C}$-ISO at a similar rate (ca 45 cells ciliate ${ }^{-1} \mathrm{~h}^{-1}$ ) (Table 8). When HYD- ${ }^{14} \mathrm{C}$-ISO was added a concentration of $4.2 \times 10^{4}$ cells $\mathrm{ml}^{-1}$, Strobilidium sp. ingested ${ }^{14} \mathrm{C}$-ISO more than 4 times as fast as $\mathrm{HYD}-{ }^{14} \mathrm{C}$ ISO. For this experiment, ciliates incubated with HYD${ }^{14} \mathrm{C}$-ISO were noticeably less motile and more prone to disintegration during the final isolation than ciliates incubated with unstained ${ }^{14} \mathrm{C}$-ISO.

\section{DISCUSSION}

This study evaluates existing and new techniques of particle preparation for use in quantitative and qualitative determination of microzooplankton herbivory in nature. Ideally, 'surrogate' prey should meet several criteria (reviewed in McManus \& Okubo 1991). Among these are the criteria that surrogate prey should be readily consumed by all components of the microzooplankton community and should be clearly visible and easily enumerated after ingestion. Second, because protozoa in culture are selective feeders, the surrogate prey should resemble naturally occurring prey as closely as possible (Spittler 1973, Heinbokel 1978, Stoecker et al. 1981). Specificially, the staining procedure should be effective with a large number of algae from different taxonomic groups with minimum effects on morphology and biochemical compositon. Protozoa should not select for or against surrogate prey relative to natural prey.

Oligotrichous and tintinnid ciliates, a number of copepodites and copepod nauplii, and some heterotrophic dinoflagellates ingested both DTAF and HYDstained algae (see also Rublee \& Gallegos 1989, Sherr et al. 1991). Heterotrophic dinoflagellates were not abundant in my samples. However both HYD- and DTAF-stained algae were consistently absent from the digestive vacuoles of several heterotrophic dinoflagel- lates (e.g. Protoperidinium sp.). A number of heterotrophic dinoflagellates digest food extracellularly (Spero 1982, Jacobsen \& Anderson 1986). Microscopic tracer techniques may not be an effective means of measuring herbivory in the heterotrophic dinoflagellates as a group. With HYD-stained algae, I had difficulty in distinguishing individual cells within the digestive vacuoles of heavily agglutinated tintinnids. This problem was particularly noticeable when the number of HYD-stained particles per individual was high, and was reduced by using short incubations or low concentrations of added algae. In general, DTAF-stained algae were more distinct than HYD-stained algae within opaque organisms.

Unfortunately, restrictions on the type and number of algal species which can be stained, as well as alterations in size and morphology, limits the utility of the DTAF technique. Rublee \& Gallegos (1989) identified several algae which were ineffectively stained by DTAF. In the present study, I obtained excellent preparations of DTAF-stained chlorophytic algae, a prasinophyte and a small diatom, but several other chromophytic algae were ineffectively stained by DTAF, apparently because they disintegrated during the heat-kill process. This problem was reduced in Isochrysis galbana by using a high salinity solution during the heat-kill/staining process. However the size of DTAF-ISO so prepared, as well as the DTAF-DUN, which was not exposed to high salt concentration prior to staining, was substantially less than for live algae.

In contrast to DTAF, I found that HYD effectively stains a wide range of chromophytic algae in a simple procedure involving minimal manipulation of algae. Negligible mechanical damage or size alteration occurred in HYD-stained cells. Chlorophytes were the only algae not effectively labelled by HYD. In subsequent applications of the HYD technique I have noted some variation among dye lots of HYD. Concentrations of 30 or occasionally $50 \mu \mathrm{g} \mathrm{ml^{-1 }}$ can be necessary to effectively stain algae. In addition to a time-zero control, I also recommend performing a control in which an 
amount of HYD equivalent to that added with the HYD-stained algae is added to an aliquot of the sample and incubated in parallel. In the present study, addition of a high concentration of HYD $\left(0.3 \mathrm{ng} \mathrm{ml}^{-1}\right)$ to samples from Vineyard Sound in which uptake of DTAF-stained particles was examined (Table 6) did not cause color development in any protozod. However, I have noted color development in several phototrophic flagellates in field samples from McMurdo Sound (Antarctica) at HYD concentrations as low as $0.14 \mathrm{ng} \mathrm{ml}^{-1}$ (Putt unpubl.). Taxa which stain at these low HYD concentrations can be easily identified in controls and omitted during enumeration of samples for particle ingestion.

I found strong food preferences among field populations of ciliates. Ingestion rates of individual ciliate taxa typically varied by over an order of magnitude for 2 species of algae (Isochrysis galbana and Pyramimonas sp.) which varied in diameter by only about $4 \mu \mathrm{m}$. Determining the effect of the method of particle preparation alone was only possible for Pyramimonas sp. because HYD- and DTAF-stained I. galbana differed in size. In their initial study, Rublee \& Gallegos (1989) reported no selection against DTAF-stained algae. I found that there was no effect of the method of particle preparation on ciliate ingestion rate when the alga in question was not readily ingested by the ciliate. Strombidium sp. B and Tintinnopsis sp. had low grazing rates on Pyramimonas sp., relative to $I$. galbana, that were not dependent on the method of particle preparation. In contrast, Strombidinopsis sp. which ingested Pyramimonas sp. twice as fast as I. galbana also ingested HYD-stained Pyramimonas sp. about twice as fast as DTAF-stained, dead Pyramimonas sp. Thus, preferences for live HYD-stained algae compared to dead DTAF-stained algae appeared to reflect whether the alga was initially a 'preferred' prey for the ciliate.

Stoecker (1988) also observed strong selectivity by Favella sp. against dead cells of its preferred food, Heterocapsa triquetra. Cell surface compounds which may be involved in particle selection may be less altered by staining with HYD than by heat-killing and staining with DTAF. In addition, live algae leak and excrete dissolved organic compounds creating a 'phycosphere' which is potentially useful in chemosensory responses and particle selection (Bell \& Mitchell 1972, Verity 1988). The 'phycosphere' would be eliminated in dead (i.e. DTAF-stained) algae whereas a 'phycosphere' which exists before addition of HYD may take some time to dissipate. Although HYD-stained algae have reduced photosynthetic rates, they may continue to excrete dissolved organic material.

The feeding preferences of ciliates observed in the present study confirm the importance of using tracer particles which are representative of naturally occurring prey. Based on my study, preparation of prey which are morphologically and biochemically representative of naturally occurring prey is difficult with the DTAF-technique. Restrictions on the type and number of algal species which can be stained with DTAF and selection against dead DTAF-stained algae present serious problems to using fluorescently labelled alage as surrogate prey.

An exciting aspect of the HYD-technique is the ease of preparation of a large number of different types of algae with minimal morphological alteration. Hydroethidine is sold as a 'vital' stain (Anonymous 1985) and has been used as such to stain freshwater ciliates (Graham 1990). However I found that motility and photosynthetic capacity of Isochrysis galbana (ISO) were almost eliminated within minutes of addition of HYD at the concentrations necessary to produce a pink color with transmitted light microscopy $\left(14 \mu \mathrm{g} \mathrm{ml}^{-1}\right.$ for Dye Lot 94344). Physiological damage apparent in the algae suggested 2 potential problems. First, HYD dissolved in seawater might also be toxic to ciliates. Dissolved HYD could be largely eliminated by washing algae before addition to the sample containing ciliates. However a washing step involving centrifugation or filtration would cause unacceptable mechanical damage to a number of fragile algae. My results indicate that concentrations of dissolved HYD up to $0.3 \mu \mathrm{g} \mathrm{ml}^{-1}$ had negligible effects on ingestion rates of ciliates collected from coastal and estuarine waters around Cape Cod. However the toxic effects of dissolved hydroethidine should be determined when the technique is used with protozoa from other geographical regions.

A second concern was that ciliates select against HYD-stained cells relative to unstained cells or suffer an indirect toxic effect resulting from ingestion of HYD. Strobilidium sp. did not select against HYD- ${ }^{14} \mathrm{C}-\mathrm{ISO}$ at concentrations up to $1.6 \times 10^{4}$ cells $\mathrm{ml}^{-1}$, i.e. a slightly higher concentration than that used in most experiments in the present study. However, at a higher algal concentration $\left(4.2 \times 10^{4}\right.$ cells $\left.\mathrm{ml}^{-1}\right)$, Strobilidium $\mathrm{sp}$. grazed HYD-stained cells at a substantially lower rate than the control. Highly reduced motility and increased fragility indicated that ingestion of HYD-stained particles had toxic effects on the ciliates. Other ciliates might vary in their sensitivity to HYD and potentially be affected at lower concentrations. However concentrations of added HYD-stained cells on the order of $10^{4}$ $\mathrm{ml}^{-1}$ are substantially higher than what would normally be used in field situations if the technique were used quantitatively (see below). Maintaining added concentrations of HYD-stained algae low and using short incubation periods are important to minimize toxicity. Toxic effects may prevent the use of HYDstained algae in long term (e.g. 24 h) time course experiments such as those used to estimate community bacterivory (Pace et al. 1990). 
The purpose of my study was to evaluate whether staining with HYD or DTAF provides a useful method of preparing surrogate prey, rather than to quantify microzooplankton herbivory in Vineyard Sound. In principle, surrogate prey should be added at levels which do not significantly alter ambient prey concentrations if the intent is to quantify in situ grazing rates (McManus \& Okubo 1991). Given a cellular chlorophyll concentration of ca $0.2 \mathrm{pg}$ cell $^{-1}$ for Isochrysis galbana (Dubinsky et al. 1986) and an added concentration of $10^{4} \mathrm{HYD} \mathrm{ISO} \mathrm{ml}^{-1}$, I added about $2 \mu \mathrm{g} \mathrm{chl} \mathrm{l}^{-1}$ as HYDISO. This is equivalent to an algal biomass roughly equal to that typical of Vineyard Sound during summer (Kana et al. 1985). Hence ingestion rates reported here likely overestimate in situ rates. Reducing added concentrations of algae to tracer levels will increase the time required to evaluate ingestion for some ciliate taxa because it will be necessary to enumerate more individuals for taxa which have low ingestion rates. However reducing added algal concentrations is desirable from the point of view that it will reduce potential toxic effects of ingestion of hydroethidine.

In culture, where food 'quality' is an important determinant of ciliate growth rate, ciliates are highly selective feeders (Stoecker et al. 1981, Verity \& Stoecker 1982, Gifford 1985, Stoecker et al. 1986, Verity \& Villreal 1986, Skogstad et al. 1987, Hansen 1989). In theory, selective grazing should influence phytoplankton community composition and protozoan growth rate in nature (Frost 1980, Stoecker et al. 1986). In practice, field studies have rarely considered selective grazing by microzooplankton except on the basis of size (Capriulo 1982, Rassoulzadegan \& Etienne 1981, but see also Lessard \& Swift 1985, Burkhill et al. 1987). With the proper experimental design, hydroethidine stained algae can be used to more fully understand the grazing preferences of natural populations of protozoa.

Acknowledgements. Discussions with Diane Stoecker about hard-boiled eggs and heat-killed algae led to this research project. Editorial comments by Goerge McManus, Diane Stoecker and an anonymous reviewer greatly improved earlier versions of the manuscript. Woods Hole Oceanographic Institution supplied facilities for much of the research. The Provasoli-Guillard Center for the Culture of Marine Phytoplankton and Dr Ralph Lewin provided algal strains. L. Davis and A. Michaels provided technical assistance. R. Ackerman assisted with photography. Research was supported, in part, by NSF-Department of Polar Programs 8816668 (M.P., and D. K. Stoecker).

\section{LITERATURE CITED}

Anonymous (1985). Hydroethidine: a new vital stain with intriguing properties. Polysciences Inc. Data Sheet No. 351. Polysciences, Warrington

Bell, W., Mitchell, R. (1972). Chemotactic and growth respon- ses of marine bacteria to algal extracellular products. Biol. Bull. mar. biol. Lab., Woods Hole 143: 265-277

Burkhill, P. H., Mantoura, R. F. C., Llewellyn, C. A., Owens, N. J. P. (1987). Microzooplankton grazing and selectivity of phytoplankton in coastal waters. Mar. Biol. 93: $581-590$

Capriulo, G. M. (1982). Feeding of field collected tintinnid microzooplankton on natural food. Mar. Biol. 71: 73-86

Dubinsky, Z., Falkowski, P. G., Wyman, K. (1986). Light harvesting and utilization by phytoplankton. Plant Cell Physiol. 27: $1335-1349$

Frost, B. W. (1980). Grazing. In: Morris, I. (ed.) The physiological ecology of phytoplankton. University of California Press, Blackwell Scientific, Los Angeles, p. 465-492

Gallegos, C. L. (1989). Microzooplankton grazing on phytoplankton in the Rhode River, Maryland: nonlinear feeding kenetics. Mar. Ecol. Prog. Ser. 57: 23-33

Gifford, D. J. (1985). Laboratory culture of marine planktonic oliogtrichs (Ciliophora; Oligotrichida). Mar. Ecol. Prog. Ser. 23: 257-267

Gifford, D. J. (1988). Impact of grazing by microzooplankton in the Northwest Arm of Halifax Harbour, Nova Scotia. Mar. Ecol. Prog. Ser 47: 240-258

Graham, J. M. (1990). Measurement of grazing rates on ciliates by freshwater copepods. In: Society of Protozoologists 43rd Annual Meeting. Proceedings. Society of Protozoologists, College Park, Maryland, Abstract no. 65

Hansen, P. J. (1989). The red tide dinoflagellate Alexandrium tamarense: effects on behaviour and growth of a tintinnid ciliate. Mar. Ecol. Prog. Ser. 53: 105-116

Heinbokel, J. F. (1978). Studies on the functional role of tintinnids in the Southern California Bight. II. Grazing rates of field populations. Mar. Biol. 47: 191-197

Herman, G. E., Stasz, T. E. (1990). Fluorescent vital stains for complementary labelling of protoplasts from Trichoderma spp. Stain Technology 63: 241-247.

Jacobsen, D. J., Anderson, D. M. (1986). Thecate heterotrophic dinoflagellates: feeding behavior and mechanisms. J. Phycol. 22: 249-258

Jonsson, P. R. (1986). Particle size selection, feeding rates and growth dynamics of marine planktonic oligotrichous ciliates (Ciliophora: Oligotrichina) Mar. Ecol. Prog. Ser. 33 : 265-277

Kana, T. M., Watts, J. L., Glibert, P. M. (1985). Diel periodicity in the photosynthetic capacity of coastal and offshore phytoplankton assemblagres. Mar. Ecol. Prog. Ser. 25: 131-139

Landry, M. R., Hassett, R. P. (1982). Estimating the grazing impact of marine micro-zooplankton. Mar. Biol. 67: $283-288$

Lessard, E. J., Swift, E. (1985). Species-specific grazing rates of heterotrophic dinoflagellates in oceanic waters, measured with a dual-label radioisotope technique. Mar Biol. 87: $289-296$

McManus, G. B., Fuhrman, J. A. (1986). Bacterivory in seawater studied with the use of inert fluorescent particles. Limnol. Oceanogr. 31 420-446

McManus, G. B., Okubo, A. (1991). On the use of surrogate food particles to measure protistan ingestion. Limnol. Oceanogr. 36: 613-617

Pace, M. L., McManus, G. B., Findlay, S. E. G. (1990). Planktonic community structure determines the fate of bacterial production in a temperate lake. Limnol. Oceanogr. 35: $795-808$

Putt, M. (1990a). Abundance, pigment content and photosynthetic rates of chloroplast retaining cillates in the Nordic Seas. Deep Sea Res. 37: 1713-1731 
Putt, M. (1990b). Metabolism of photosynthate in the chloroplast-retaining ciliate Laboea strobila. Mar. Ecol. Prog. Ser. 60: 271-282

Rassoulzadegan, F. (1978). Dimensions et taux d'ingestion des particules consommées par un tintinnide: Favella ehrenbergii (Clap. et Lachm.) Jorg., cilie pelagique marin. Ann. Inst. Oceanogr. Paris 54: 17-24

Rassoulzadegan, F., Etienne, M. (1981). Grazing rate of the tintinnid Stenosemella ventricosa (Clap. and Lachm.) Jorg. on the spectrum of the naturally occurring particulate matter from the Mediterranean neritic area. Limnol Oceanogr. 26: 258-270

Rublee, P. A., Gallegos, C. L. (1989). Use of fluorescently labelled algae (FLA) to estimate microzooplankton grazing. Mar. Ecol. Prog. Ser. 51: 221-227

Sanders, R. W. (1988). Feeding by Cyclidium sp. (Ciliophora, Scuticociliatidal on particles of different sizes and surface properties. Bull. mar. Sci. 43: 446-457

Sherr, B. F., Sherr, E. B., Fallon, R. D. (1987). Use of monodispersed, fluorescently labeled bacteria to estimate in situ protozoan bacterivory. Appl. environ. Microbiol. 53: 958-965

Sherr, E. B., Sherr, B. F., McDaniel, J. (1991). Clearance rates of $<6 \mu \mathrm{m}$ fluorescently labeled algae (FLA) by estuarine protozoa: potential grazing impact of flagellates and ciliates. Mar. Ecol. Prog. Ser. 69: 81-92

Sherr, E. B., Sherr, B., F., Pfaffenhöfer, G. A. (1986). Phagotrophic protozoa as food for metazoans: a 'missing' trophic

This article was presented by M. Levandowsky, New York, USA link in marine pelagic food webs. Mar. Microb. Food Webs 1: $61-80$

Skogstad, A. L., Granskog, L., Klaveness, D. (1987). Growth of freshwater ciliates offered planktonic algae as food. J. Plankton Res. 9: 503-512

Spero, H. J. (1982). Phagotrophy in Gymnodinium fungiforme (Pyrrophyta): the peduncle as an organelle of ingestion. J. Phycol. 18: 356-360

Spittler, P. (1973). Feeding experiments with tintinnids. Oikos (Suppl.) 15: 128-132

Stoecker, D. K. (1988). Are marine planktonic ciliate suspension-feeders? J. Protozool. 35: 252-559

Stoecker, D. K., Cucci, T. L., Hurlburt, E. M., Yentsch, C. M. (1986). Selective feeding by Balanion sp. (Ciliata: Balanionidae) on phytoplankton that best support its growth. J. exp. mar. Biol. Ecol. 95: 113-130

Stoecker, D. K., Guillard, R. R. L., Kavee, R. M. (1981). Selective predation by Favella ehrenbergii (Tintinnia) on and among dinoflagellates. Biol. Bull. mar. biol. Lab., Woods Hole 160: 136-145

Verity, P. G. (1988). Chemosensory behavior in marine planktonic ciliates. Bull. mar. Sci. 43: 722-782

Verity, P. G., Stoecker, D. K. (1982). Effects of Olisthodiscus luteus on the growth and abundance of tintinnids. Mar Biol. 72: 79-87

Verity, P. G., Villreal, T A. (1986). The relative food value of diatoms, dinoflagellates, flagellates and cyanobacteria for tintinnid ciliates. Arch. Protistenkde. 131: 71-84

Manuscript first received: November 15, 1990

Revised version accepted: August 6, 1991 